\title{
THE EFFECTIVENESS OF INTERACTIVE INTEGRATED SCIENCE E-MODULE WITH CONNECTED TYPE TO IMPROVE STUDENT'S MASTERY ON ENERGY TOPIC
}

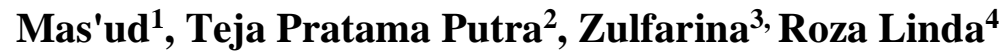 \\ ${ }^{1,2,4}$ Postgraduate Education Program, Universitas Riau \\ ${ }^{3}$ Faculty of Teachers Training and Education, Universitas Riau
}

Corresponding author: rozalinda@gmail.com

\begin{abstract}
Article Info
Abstract

Received: 25 July 2021

Efforts to improve the quality of Integrated Science learning for

Accepted: 25 October 2021 junior high schools in the era of globalization that are following the Published: 26 October 2021 challenges of 21 st-century education can be done through the use of connected type interactive e-modules. The study was conducted to determine the effectiveness of the e-module on students' mastery of

Keywords:

Effectiveness; interactive Emodule; concept mastery; energy energy concepts. The research method used is a descriptive quantitative quasi-experimental type with a matching-only pretestposttest control group design. The research was conducted in one of the public junior high schools in Bangkinang with a purposive sampling technique. Data were collected using research instruments in the form of mastery of concepts in energy material. Data analysis was performed using pre-requisite test, statistical test (different test; t-test), and N-Gain test. The results obtained show that the use of the connected type of integrated science interactive e-module can improve students' mastery of concepts on energy material in the experimental class with the medium category.
\end{abstract}

\section{INTRODUCTION}

Education in the 21st Century requires students to learn with not just conventional academic learning that emphasizes the authority of educators in learning. Rather, it is education that offers learning services that enable them to collaborate, communicate, solve problems, think critically, creatively, and innovatively. These abilities or skills can only be realized through learning that no longer relies on face-to-face learning, but a combination of online learning (e-learning) and face-to-face learning, or known as Blended Learning (Kristanto, 2017). Blended learning requires optimizing the use of technology as an educational tool which is expected to be able to produce creative, innovative, and competitive generations to face the era of the Industrial Revolution 4.0. 
With the Industrial Revolution 4.0, teachers must improve their quality so that they can become teachers who can produce higher quality human resources (Wahyuni, 2018).

The era of the Industrial Revolution 4.0 requires teachers to make changes in the field of education both in terms of learning models, the ways of learning, and learning resources. "Making Indonesia 4.0" is a movement that is the government's commitment to entering the era of the Industrial Revolution 4.0. In preparing to enter the Industrial Revolution 4.0, several changes were made in implementing learning methods in schools: 1) Changing the nature and mindset, 2) Honing and developing talents, and 3) Changing the learning model according to the needs of the times.

The government's policy on the zoning-based new student admission system (PPDB) in public schools does not provide opportunities for schools to carry out selections with certain criteria, this causes the student input in one school to be very heterogeneous. So that, teachers need to be creative till learning in class is interesting and quality. In learning, the quality and achievement of learning objectives are strongly influenced by the factors of learning methods and the use of teaching materials (Burgess \& Ice, 2011; Loveless, et al., 2006). Today, many learning methods are verbalized and tend to only use the blackboard, as well as the lack of effort to conduct demonstrations/ experiments, the teaching materials used still use printed teaching materials.

Science learning in schools is one of the compulsory curriculum content which aims to make students able to: (1) Live life with a positive, honest and open attitude with critical, creative, and innovative thinking and collaborate based on the nature of science (2) Understand the natural phenomena around them based on the results of integrated science learning through specific fields namely physics, chemistry and biology (3) Evaluate the products of thought that exist in the community based on scientific principles nature and ethics (4) Solving problems and making decisions in life based on scientific and ethical principles (5) Recognizing and playing a role in efforts to solve human problems, such as problems of food availability, health, energy crises, and the environment, and (6) Understand the impact of the development of science in an integrated manner on the development of technology and human life in the past, present and potential future impacts for themselves, others and the environment (Kemdikbud, 2018).

Science learning given in Junior High Schools (SMP) is packaged in integrated science learning. The integrated science of Junior High Schools (SMP) in Indonesia is under the science curriculum which combines the fields of study of physics, chemistry, and biology, earth and space sciences, as well as technology and society. In science learning so far it tends to be teacher-centered, students are in low-level domains, students are not wonted to high order thinking (Muslim et al., 2018; Sun et al., 2020). Students are created like robots that can only enter numbers and memorize. The essence contained in science learning itself was not included in the memory of students (Sun et al., 2020). This is very far from the expectations of science learning itself and is not under the central view of the 2013 Curriculum that science learning in students tends to study science as a product, memorizing concepts, theories, and laws (Gunawan, 2017). This situation was influenced

International Journal of Educational Best Practices (IJEBP)

Vol.5 No.2 October 2021

ISSN: 2581-0847

DOI: 10.32851/ijebp.v5n2.p211-222 
by test-oriented learning. As a result, science as a process, attitude, and application was not touched in learning. This situation requires teachers to always innovate both in learning and preparing teaching materials such as modules (Anugraheni, 2019).

The results of observations and interviews with science teachers from several schools found several facts, the first fact, it was found that student learning outcomes, especially students' concept mastery in science subjects for energy topic on 2019/2020 academic year at SMPN 1 Bangkinang Kota showed that only $71 \%$ achieved Minimum Completeness Criteria (KKM) with the KKM for science subjects is 72 on a scale of 100 and at SMPN 1 Kampar only $70 \%$ achieved the KKM with KKM for science being 73 on a scale of 100. While teachers complained that they lacked knowledge about integrated science and the teaching materials provided did not fully cover integrated science. Based on the results of interviews with science teachers at SMPN 2 Bangkinang Kota and SMPN 1 Kampar, information was obtained that in fact science teachers have not taught science in an integrated manner. Science is still taught separately between physics, chemistry, and biology. Many obstacles cause teachers to not apply science in an integrated manner, namely; (1) Teachers come from educational backgrounds in physics, chemistry, and biology, and there are even non-science teachers who have to teach science, (2) Books provided by the government have not presented science in an integrated manner, and (3) The limited ability of teachers to design integrated science teaching materials. This is also in line with research conducted by Stephen (2015) that teachers do not have the skills and strategies in developing teaching materials so that it hampers the learning and teaching process.

In accordance due to the development of the Globalization Era and the challenges of education to the 21st Century, especially in the era of the Industrial Revolution 4.0, it urges high creativity teachers to make quality learning. Education should ideally be able to keep up with technological developments and use it as a very sophisticated facility in learning (Rohida, 2018). Teacher creativity can be expressed in the use of digital teaching materials, such as interactive e-modules as independent teaching materials that directly provide feedback and can be used anytime and anywhere before school learning begins, so that afterward interactive discussions can be held, to achieve student competence in terms of knowledge, skills, and attitudes as a whole, in accordance with the 2013 Curriculum design (Loveless et al., 2006; Asmiyunda et al., 2018). In addition, based on pre-research on teachers and students of class IX SMP Negeri 1 Bangkinang Kota, SMPN 2 Bangkinang Kota, and SMPN 1 Kampar, information was obtained that the teaching materials commonly used are printed teaching materials in the form of textbooks, Students' Worksheets (LKPD), photocopies of questions and also digital teaching materials in the form of PowerPoint text (PPT).

Energy is one of the themes on integrated science subjects for Junior High Schools (SMP) which is a continuation for Elementary Schools (SD). In general, from the view of Setiyawati (2011) regarding the connected type of integrated science in the energy topic consisting of materials in the fields of physics, chemistry, and biology presented in a concrete way between concepts in various fields of science and this connection can be held spontaneously or planned in advance. Specifically, the concept of physics in the

\section{International Journal of Educational Best Practices (IJEBP)}

Vol.5 No.2 October 2021

ISSN: $2581-0847$

DOI: 10.32851/ijebp.v5n2.p211-222 
energy theme discusses the first law of thermodynamics, the concept of biology discusses the transformation of energy through the body's metabolism and the concept of chemistry discusses chemical reactions during the body's metabolic processes.

The connectedness of concepts in the energy topic can be expressed in an interactive emodule for integrated science which has the urgency to increase the students' concept mastery and insights of students in order to achieve the competencies demanded by the 2013 Curriculum as a whole (Putri, 2019; Weri, 2019). The ease of mastering the concepts presented is also expected to provide more contextual and meaningful situations and conditions, so that students do not just memorize concepts but master concepts and can apply them in everyday life (Putri, 2019).

A relevant study conducted by Linda, et al. (2021), shows that the implementation of an interactive e-module of integrated science with connected type was is known to increase learning independence and student learning outcomes. The self-instructional characteristics of e-modules cause students not to depend on others in their learning, in addition, e-modules can also provide a complete learning experience, considering that the material presented in the e-module is a unified whole (self-contained) (Prastowo, 2011; Li, 2016; Hargis et al., 2014; Dewi \& Primayana, 2019). Oktamagia et al. (2013), explained that the low learning outcomes of science (physics) in Junior High School (SMP) are caused by a lack of students' understanding of a concept and students' inability to think independently. One of the ways to increase students' understanding is by using the integrated learning type connected.

Through the interactive e-module of integrated science with connected type that has been developed on the previous research, this research is carried out to determine the effectiveness of that e-module to increase the students' concept mastery in energy topic. Through a review of the relevant literature, the hypothesis of this research is the use of interactive e-module of integrated science with connected type is effective in increasing students' mastery of concepts in energy topic.

\section{METHODS}

Effectiveness of interactive e-module of integrated science with connected type to improve students' concept mastery on energy topic using a quantitative descriptive research method. This type of research is classified as quasi-experimental with the matching-only pretest-posttest control group design. This research was designed by involving two research groups, namely the experimental and control classes. The two classes were given different treatments. After completion, the measurement (posttest) of the results obtained from the treatment was carried out. The data obtained were then compared and analyzed with data before using the product as a pretest component (Rusdi, 2018). Learning activities in the control class began with giving appreciation, motivation and delivery of learning objectives. The explanation of teaching materials is

\section{International Journal of Educational Best Practices (IJEBP)}


carried out with a scientific approach using teaching materials in the form of printed books provided by schools. While in the experimental class the teaching materials used are interactive e-modules. Learning evaluation activities are carried out using evaluation instruments in the form of concept mastery questions for the two classes.

Implementation was carried out at SMP Negeri 1 Bangkinang Kota. The sample was obtained through the purposive sampling technique. The sample selection was based on research needs through teacher recommendations for the dominant students in the control class who have smartphones that are compatible with installing e-modules in the form of Android applications. The sample in this study was 30 students from class VII A (experimental class) and 30 students from VII B (control class) of SMP Negeri 1 Bangkinang Kota for the 2020/2021 academic year.

Data collection techniques were carried out using research instruments in the form of learning outcomes test questions (pretest and posttest) which were accessed via Google Form. The research procedure was carried out following the stages, namely conducting a pretest to students, distributing e-module and directing students to download and install it on smartphones by facilitating video tutorials (experimental class, while the control class did not), implementing e-modules on every meeting (four meetings) as a treatment in research assisted by Google Classroom and Zoom Meeting (experimental class, while the control class was not), and ended by conducting posttest to students.

Data analysis was carried out and started with pre-requisite testing, namely normality and homogeneity tests from the pretest and posttest data for students' concept mastery through the Kolmogorov-Smirnov test and Levene test. This is followed by a statistical test (hypothesis) using the Independent Sample t-Test to test whether or not there is a difference in the mean between the two unrelated research groups. Both of these tests were carried out at a significance level of 0.05 with the help of SPSS 23.

The analysis of increasing students' concept mastery was carried out by using the $\mathrm{N}$ Gain test. Data on students' concept mastery scores were obtained from the accuracy of the answers to each question in the pretest and posttest. Each correct answer is given a score of 1 and the wrong answer is given a score of 0 . The tabulation of the data was then categorized into types of improvement using the $N$-Gain test with the categories in Table 1.

Table 1. Improving concept mastery category

\begin{tabular}{cc}
\hline N-Gain & Improving Concept Mastery Category \\
\hline $\mathrm{G}>0.7$ & High \\
$0.3 \mathrm{G} 0.7$ & Medium \\
$\mathrm{G}<0.3$ & Low \\
\hline
\end{tabular}

International Journal of Educational Best Practices (IJEBP)

Vol.5 No.2 October 2021

ISSN: 2581-0847

DOI: 10.32851/ijebp.v5n2.p211-222 
(Hake, 2015)

\section{FINDINGS AND DISCUSSION}

\section{Findings}

Data on the results of students' concept mastery of energy topic obtained in the pretest and posttest for the experimental and control classes are summarized in Figure 1.

\section{Figure 1: of pretest and posttest percentage of students' concept mastery of energy topic}

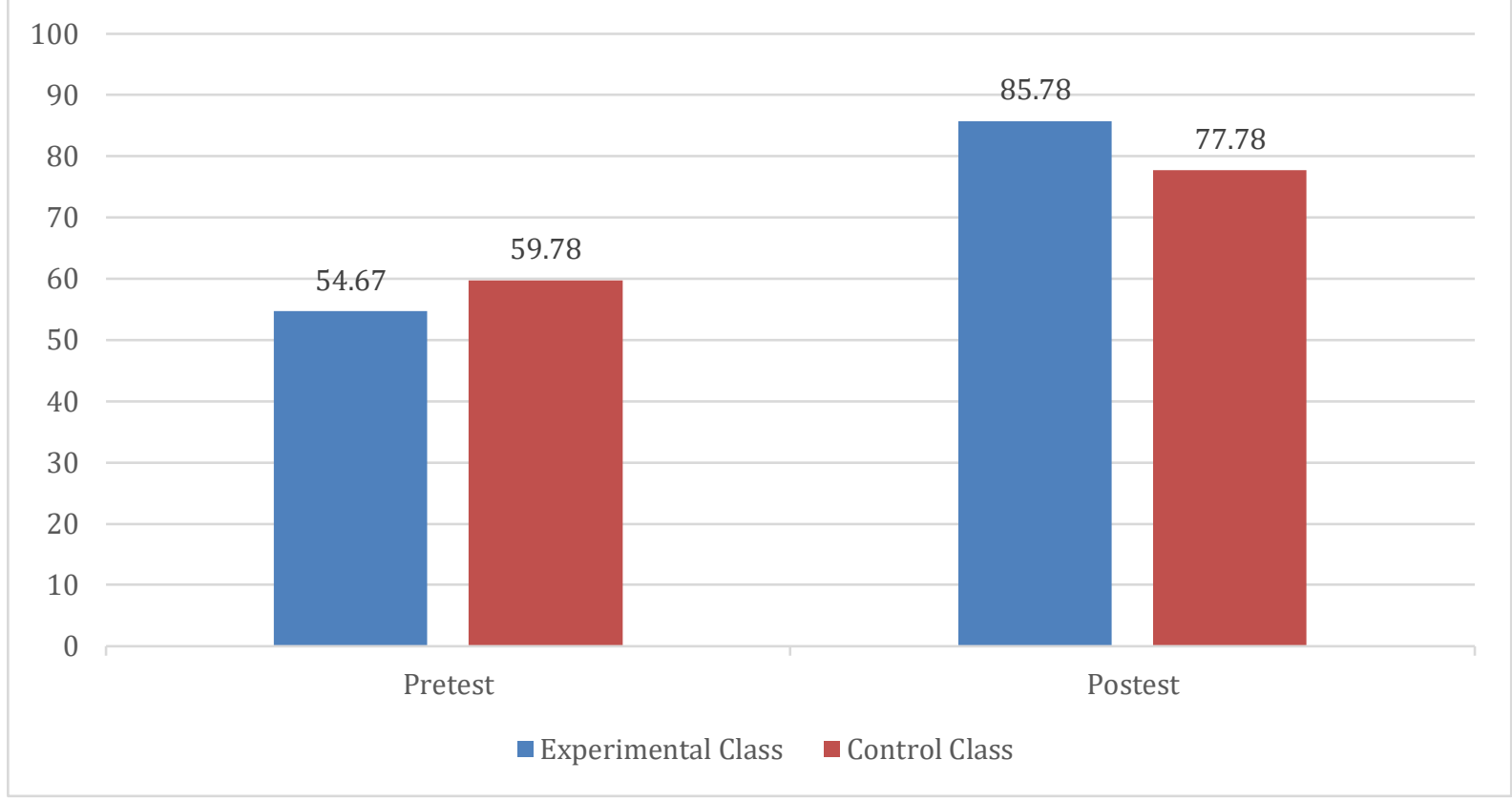

Based on Figure 1., it was known that the percentage of pretest in experimental class and control class was low, therefore the use of interactive e-module of integrated science with the connected type expected to improve students' concept mastery of energy topic, especially as treatment in the experimental class. Meanwhile, the percentage of posttest had increased compared to the previous one. However, there was a difference in the percentage of the two classes, namely posttest' percentage in the control class is lower than the experimental class.

In the pre-requisite test, the normality and homogeneity test of the pretest and posttest through the Kolmogorov-Smirnov test and Levene test indicated that the students' concept mastery in the experimental and control classes were normally distributed and homogeneous, as shown in Table 2. 
Table 2. The result of normality and homogeneity test of students' concept mastery

\begin{tabular}{cccccc}
\hline \multirow{2}{*}{ Data } & \multirow{2}{*}{ Concept Mastery } & \multicolumn{2}{c}{ Kolmogorov-Smirnov } & \multicolumn{2}{c}{ Levene } \\
& Sig & Explanation & Sig & Explanation \\
\hline \multirow{2}{*}{ Pretest } & Experimental Class & 0.555 & Normal & \multirow{2}{*}{0.13} & \multirow{2}{*}{ Homogeneous } \\
& Control Class & 0.626 & Normal & & \\
\multirow{2}{*}{ Posttest } & Experimental Class & 0.591 & Normal & \multirow{2}{*}{0.16} & Homogeneous \\
& Control Class & 0.448 & Normal & & \\
\hline
\end{tabular}

The normal and homogeneous data of the posttest were then analyzed by $t$-test to test whether or not there was a significant difference between the experimental and control classes.

Table 3. Significance data between the experimental and control classes

\begin{tabular}{|c|c|c|c|c|c|c|c|c|}
\hline \multicolumn{2}{|c|}{$\begin{array}{c}\text { Levene Test } \\
\text { for Equality of } \\
\text { Variances }\end{array}$} & \multicolumn{7}{|c|}{ t-Test for Equality of Means } \\
\hline \multirow{2}{*}{\multicolumn{2}{|c|}{ Sig. }} & \multirow[t]{2}{*}{$\mathrm{t}$} & \multirow[t]{2}{*}{$\mathrm{df}$} & \multirow[t]{2}{*}{$\begin{array}{l}\text { Sig. (2 } \\
\text { tailed) }\end{array}$} & \multirow[t]{2}{*}{$\begin{array}{c}\text { Mean } \\
\text { Difference }\end{array}$} & \multirow[t]{2}{*}{$\begin{array}{l}\text { Std. Error } \\
\text { Difference }\end{array}$} & \multicolumn{2}{|c|}{$\begin{array}{l}95 \% \text { Confidence } \\
\text { Interval of the } \\
\text { Difference }\end{array}$} \\
\hline & & & & & & & Lower & Upper \\
\hline 6.211 & 0.016 & 2.317 & 58 & 0.024 & 8.000 & 3.453 & 1.087 & 14.912 \\
\hline
\end{tabular}

Based on Table 3., the known value of the t-test showed that significance $(\alpha)<0.05$ (see sig. $=0.024$ in Table 3 ), then the decision is $\mathrm{H}_{0}$ is rejected, meaning that there is a significant difference in the posttest for students' concept mastery between the experimental class and the control class. Thus, the use of interactive e-module in the experimental class was found to be effective in increasing the mastery of science concepts for junior high school students.

Increased students' concept mastery was known through the N-Gain test as shown in Table 4.

Table 4. Results of N-Gain test

\begin{tabular}{ccccc}
\hline \multirow{2}{*}{ Level } & \multicolumn{2}{c}{ Experimental Class } & \multicolumn{2}{c}{ Control Class } \\
& $\mathrm{N}$-Gain & Category & $\mathrm{N}$-Gain & Category \\
\hline
\end{tabular}




\begin{tabular}{ccccc}
\hline C1 & 0.74 & High & 0.65 & Moderate \\
C2 & 0.74 & High & 0.49 & Moderate \\
C3 & 0.63 & Moderate & 0.28 & Low \\
C4 & 0.64 & Moderate & 0.39 & Moderate \\
Total & 0.69 & Moderate & 0.45 & Moderate \\
\hline
\end{tabular}

\section{DISCUSSION}

The value of students' concept mastery of the experimental class got a higher average than the control class in the posttest. Factors that influence the difference between experimental and control classes are the learning experiment class using interactive emodule of integrated science with connected type as a learning material on energy topic, while the learning control class still uses textbooks from the Ministry of Education and Culture (Kemdikbud). This is in line with the results of UZ et al. (2019) which shows that students' concept mastery in the learning process using e-module and not, has a significant difference. It can be concluded that the use of interactive e-module of integrated science with connected type on energy topic was declared effective in increasing the students' concept mastery for Junior High School (SMP).

The use of this e-module as teaching material in the learning process can cause students to be interested in learning because the learning material contained the multimedia elements (audio, video, animation, and pictures) that can be included in the e-module, so that really helps students to understand learning material and with this e-module, the learning process is more interesting and fun (Serevina et al., 2018; UZ et al., 2019). Yustanti \& Novita (2019) stated that learning media that utilize technology will provide benefits in the form of convenience for students in understanding learning materials so that optimal results are obtained.

The increase of students' concept mastery was seen based on the level of mastery of concepts adopted from the cognitive domain of the revised Bloom's Taxonomy, namely: C1 (remembering), C2 (understanding), C3 (applying), and C4 (analyzing) (Anderson \& Krathwol, 2004) which are sorted through a grid of indicators about mastery of concepts. Based on Table 4., it was known that the $N$-Gain value of the students' concept mastery in the experimental class was increased in the cognitive domains $\mathrm{C} 1$ (remembering) and C2 (understanding) by 0.74 with a high increase category. Overall, there was an increase in students' concept mastery, namely, 0.69 for the experimental (moderate category) and 0.45 for the control class (moderate category). Although the experimental and control classes both are increase, the experimental class was greater than the control class, namely $0.69>0.45$. 
The increase in students' concept mastery in the experimental class is due to the learning process of energy topic using interactive e-module of integrated science with connected type. E-module that are used provide a special attraction for students in understanding, this has been proven by Istuningsih et al. (2018) that a good understanding of students can affect achieving the optimal results of the learning process. The use of e-module can also improve students' cognitive abilities due to individual teaching and improvement of information technology skills (Pramana et al., 2006).

\section{CONCLUSION}

The use of interactive e-module of integrated science with connected type can improve students' concept mastery on energy topic with an increase of $31.11 \%$. This increase is in the moderate category with an $\mathrm{N}$-Gain value of 0.69 . So the use of interactive e-module is an alternative teaching material that can be used to improve students' mastery of concepts. The limitations of this research are purposive sampling and testing of one variable. For the further research expected can use more samples and compare the types of teaching materials used.

\section{REFERENCES}

Anderson, L.W. \& Krathwohl, D.R. (2004). A Taxonomy for Learning, Teaching, and Assessing: a Revision of Bloom's Taxonomy. Longman Publishing: New York.

Anugraheni, P. (2019). Pembelajaran 5E Learning Cycle Berbantuan Multi Media Dalam Pembelajaran IPA Terpadu Webbed Untuk Meningkatkan Minat Belajar dan Keterampilan Berpikir Kritis Pada Tema Kulihat Dunia Dengan Mata. Tesis. Universitas Pendidikan Indonesia.

Asmiyunda, A., Guspatni, G., \& Azra, F. (2018). Pengembangan E-Modul Kesetimbangan Kimia Berbasis Pendekatan Saintifik Untuk Kelas XI SMA/MA. Jurnal Eksakta Pendidikan, 2(2), 155-161.

Burgess, M. L. \& Ice, P. (2011). Using the Community of Inquiry (CoI) Model and Bloom's Revised Taxonomy to Support 21st Century Teaching and Learning in Multi User Virtual Environments. Cutting Edge Technologies in Higher Education, $4,163-186$. 
Dewi, P.Y. \& Primayana, K.H. (2019). Effect of Learning Module with Setting Contextual Teaching and Learning To Increase The Understanding of Concepts. International Journal of Education and Learning, 1(1), 19-26.

Gunawan, I. (2017). Indonesian Curriculum 2013: Instructional Management, Obstacles Faced by Teachers In Implementation and The Way Forward. In 3rd International Conference on Education And Training.

Hake, R. 2015. Analyzing Change/ Gain Scores.

Hargis, J., Cavanaugh, C., Kamali, T., \& Soto, M. (2014). A Federal Higher Education iPad Mobile Learning Initiative: Triangulation of Data To Determine Early Effectiveness. Innovative Higher Education, 39(1), 45-57.

Istuningsih, W., Baedhowi, B., \& Sangka, K.B. (2018). The Effectiveness of Scientific Approach Using E-Module Based on Learning Cycle 7e To Improve Students' Learning Outcome. International Journal of Educational Research Review, 3(3), $75-85$.

Kemdikbud. (2018). Silabus Mata Pelajaran Sekolah Menengah Pertama/ Madrasah Tsanawiyah (SMP/MTs) Mata Pelajaran Ilmu Pengetahuan Alam. Jakarta: Kementerian Pendidikan Dan Kebudayaan.

Kristanto, A. (2017). The Development of Instructional Materials E-Learning Based on Blended Learning. International Education Studies, 10(7), 10-17.

Li, Y.W. (2016). Transforming Conventional Teaching Classroom To Learner Centred Teaching Classroom Using Multimedia Mediated Learning Module. International Journal of Information and Education Technology, 6(2), 105-112.

Linda, R., Zulfarina, Z., \& Putra, T.P. (2021). Peningkatan Kemandirian dan Hasil Belajar Peserta Didik Melalui Implementasi E-Modul Interaktif IPA Terpadu Tipe Connected Pada Materi Energi SMP/MTs. Jurnal Pendidikan Sains Indonesia, 9(2), 191-200.

Loveless, A., Burton, J., \& Turvey, K. (2006). Developing Conceptual Frameworks for Creativity, ICT and Teacher Education. Thinking Skills and Creativity, 1(1), 3-13.

Muslim, S., Gitama, N. P., Suprianto, B., Rahmadyanti, E., \& Kusumawati, N. (2018). Influence of Learning Media Based on Adobe Flash Professional To Psychomotor Domain Learning Outcomes on PLC Courses Viewed From Level Of Creative Thinking Student. Jurnal Pendidikan Vokasi, 8(3), 267-276. 
Oktamagia, D.W. (2013). Pengaruh Pembelajaran Terpadu Tipe Connected Terhadap Hasil Belajar IPA Fisika Pada Materi Cahaya dan Alat Optik di Kelas VIII SMP N 1 Sungai Tarab. Pillar of Physics Education, 2(1).

Pramana, W.D., \& Dewi, N.R. (2014). Pengembangan E-Book IPA Terpadu Tema Suhu dan Pengukuran Untuk Menumbuhkan Kemandirian Belajar Siswa. UNNES Science Education Journal, 3(3).

Prastowo, A. (2011). Panduan Kreatif Membuat Bahan Ajar Inovatif. Yogyakarta: DIVA Press.

Putri, T. A. (2019). Integrated Science Analysis of Student Text Books with The Theme Of Blood Fluids Using Integrated Connected Type 21st Century Learning. In Journal of Physics: Conference Series, 1185(1), 012110. IOP Publishing.

Rohida, L. (2018). Pengaruh Era Revolusi Industri 4.0 Terhadap Kompetensi Sumber Daya Manusia. Jurnal Manajemen dan Bisnis Indonesia, 6(1), 114-136.

Rusdi, M. (2018). Penelitian Desain dan Pengembangan Kependidikan. Depok: PT. Raja Grafindo Persada.

Serevina, V. (2018). Development of E-Module Based on Problem Based Learning (PBL) on Heat and Temperature to Improve Student's Science Process Skill. Turkish Online Journal of Educational Technology-TOJET, 17(3), 26-36.

Setiyawati, E. (2011). Pengembangan Kompetensi Ilmiah Siswa Berorientasi Model Pembelajaran Terpadu Tipe Connected. PEDAGOGIA: Jurnal Pendidikan, 1(1), 11-20.

Stephen, U.A.S. (2015). Problems of Improving Instructional Material for The Teaching And Learning Of Physics In Akwa Ibom State Secondary Schools, Nigeria. British Journal of Education, 3(3), 27-35.

Sun, M., Wang, M., \& Wegerif, R. (2020). Effects of Divergent Thinking Training on Students' Scientific Creativity: The Impact of Individual Creative Potential and Domain Knowledge. Thinking Skills and Creativity, 37, 100682.

UZ, L. Z., Haryono, H., \& Wardani, S. (2019). The Development of Chemical E-Module Based on Problem of Learning To Improve The Concept of Student Understanding. Innovative Journal of Curriculum and Educational Technology, 8(2), 59-66.

Wahyuni, D. (2018). Peningkatan Kompetensi Guru Menuju Era Revolusi Industri 4.0. Info Singkat (Kajian Singkat Terhadap Isu Aktual dan Strategis) Pusat Penelitian Badan Keahlian DPR RI 2018 X, No. 24/II/Puslit/Desember, 13-18. 
Weri, F. (2019). Analysis of Student Textbook In The Development of Integrated Natural Science Student Book With The Theme Sense of Sight and Optical Devices Using Connected Model for Integrated 21st Century Learning. In Journal of Physics: Conference Series, 1185(1), 012113. IOP Publishing.

Yustanti, I. \& Novita, D. (2019). Pemanfaatan E-Learning Bagi Para Pendidik Di Era Digital 4.0. Seminar Nasional Pendidikan Program Pascasarjana Universitas PGRI Palembang, 2(2), 5-41. 